\title{
Labor Market Insiders or Outsiders? A Cross-National Examination of Redistributive Preferences of the Working Poor
}

\author{
Asaf Levanon \\ Department of Sociology, Faculty of Social Sciences, Mount Carmel, Haifa 31905, Israel; \\ alevanon@univ.haifa.ac.il
}

Received: 30 May 2018; Accepted: 27 August 2018; Published: 31 August 2018

\begin{abstract}
Prior research on attitudes toward redistribution documents an association between one's policy preferences and socioeconomic position, as well as an impact of welfare policy on the mean level of support for redistribution. Building on both traditions, the current paper aims to expand our understanding of the sources of public support for welfare policies by examining the role that social policy plays in shaping the policy preferences of the working poor. Building on the distinction between labor market insiders and outsiders, this paper examines whether preferences by the working poor more closely resemble those of non-poor workers or those of non-working poor individuals. Results from this study show that the degree of support for redistribution among the working poor is notably closer to the average degree reported by non-working poor individuals than the mean level reported by non-poor workers. Moreover, utilizing cross-national data from 31 countries in 13 different time-points between 1985 and 2010, the paper documents a much smaller preference gap between non-poor workers and the working poor and a higher overall level of support for redistribution in countries providing a greater degree of employment protection.
\end{abstract}

Keywords: preference for redistribution; stratification/inequalities; working poor; labor market insiders-outsiders

\section{Introduction}

The association between one's socioeconomic location and one's social policy preferences has long been at the center of sociological attention and imagination (e.g., [1-6]). A prominent view on this association suggests that people with disadvantaged economic positions have greater material interests in redistributive policy, while those with more advantaged positions are expected to oppose such policies, mainly because of their implications for tax policy. This argument has received considerable empirical support [7-20]. An accompanying and more recent strand of research has focused on contextual influences on these differences in support for redistribution, with a particular emphasis on welfare policy $[8,9,11,13,19,21-25]$. Motivated by Esping-Andersen's [26,27] typology of welfare regimes, research in this tradition generally documents greater support for redistributive policies in social democratic countries than in conservative countries, with the liberal countries typically exhibiting the lowest levels of support.

Building on both traditions, the current paper aims to expand our understanding of the sources of public support for welfare policies by examining the role that social policy plays in shaping the policy preferences of the working poor. This focus provides two important contributions to the literature. First, in contrast to prior conceptualizations of socioeconomic position as additively composed of employment status and occupational status or income, the current paper focuses on the intersection of income and employment. While work and poverty are often understood as incompatible 
statuses [28-32], working poverty is not uncommon in most countries. Recent reports suggest that the rate of working poverty in advanced economies is about $7 \%[28,33]$. In addition, on average, workers account for $60 \%$ of the poor in OECD countries. In some countries (e.g., Austria, Canada, Israel and Spain), the working poverty rate has been drastically increasing in recent decades [28,34]. Building on the distinction between labor market insiders and outsiders [27,35-38], the paper will specifically examine if preferences by the working poor more closely resemble those of non-poor workers or those of non-working poor individuals. This analysis will provide a more nuanced view on the role of economic position and self interest in shaping redistribution preferences, allowing the identification of the potentially different implications of employment status and income.

Second, utilizing cross-national data from 31 countries in 13 different time points between 1985 and 2010, the current paper examines whether policy preferences by the working poor, as well as other groups, are shaped by specific social policies. Instead of examining differences across welfare regimes in popular support for redistribution, the paper adopts an approach that suggests that a direct assessment of the expectations arising from the welfare regimes approach involves examining the association between specific welfare policies and redistributive preferences [13,39-41]. This approach will allow examining whether institutional differences across countries are associated with shifts in the perceptions of the working poor, thereby increasing their similarity in preferences with either non-poor workers or non-working poor individuals. The paper follows prior research in examining the role of unemployment benefits and active labor market policy [13]. However, building on the insider-outsider approach, the paper also directs attention to employment protection legislation, which has direct implication for the view of working poverty as a transient or stable labor market status.

\section{Theoretical Considerations}

The current paper aims to expand our understanding of the sources of public support for welfare policies by examining the role that social policy plays in shaping the policy preferences of the working poor. To establish the rationale for focusing on the working poor, this section will start with a discussion of the literature on socioeconomic cleavages in support for redistributive policies. Next, the section will include a discussion of cross-national differences overall and the social basis of support for redistribution. The section will conclude by presenting an insider-outsider argument regarding the support for social policies, which will motivate the research questions on the preferences by the working poor and their associations with social policy.

\subsection{Socioeconomic Differences in the Support for Redistributive Policies}

Socioeconomic differences in the level of support for redistribution are commonly explained in the literature as reflecting a rational calculation motivated by material self-interest $[7,8,10,12,14-18,42,43]$. According to this explanation, which is usually referred to as the "self-interest hypothesis", different socioeconomic positions are associated with divergent control over material resources, which is, in turn, associated with different life prospects. Aiming to maintain their status, individuals holding relatively advantaged social positions are expected to favor a lower tax rate and a reduced role for the government in equalizing life chances across individuals. The calculation carried out by these individuals supposedly factors both the lower likelihood of receiving benefits from redistributive policies and the higher tax rate they will have to pay in order to fund such policies. By contrast, persons in disadvantaged socioeconomic positions are expected to favor policies that will improve their status by redistributing economic resources and insuring against social risks. To the extent that funding is secured through progressive taxation, these people are unlikely to carry the lion's share of the tax burden if such policies are enacted.

The self-interest hypothesis has received considerable empirical support. Past research has documented a higher likelihood of supporting welfare policies among low income individuals, persons holding disadvantaged class positions and the unemployed [7,9,11-13,15,19,25]. Furthermore, cross-national research suggests that these differences are exacerbated by deteriorating macro-economic 
conditions [9]. A more direct attempt at establishing the causal link between socioeconomic position and welfare attitudes comes from studies documenting the impact of changes in personal circumstances on welfare attitudes [17,44]. Owens and Pedulla [17], for example, report that when individuals experience an unemployment spell or a loss of household income, their support for redistributive policies increases. Additional support comes from experimental studies that show that people are more likely to support welfare policies when their stakes in the policy are made clear [45]. Not all prior research provides supporting evidence (e.g., [46-48]). Lynch and Myrskylä [46], for instance, do not find greater support for public pension programs among potential self-interested beneficiaries.

The aforementioned support notwithstanding, several accounts have challenged the role of self-interest in motivating redistributive preferences. First, the values perspective suggests that redistributive preferences are not influenced only by material circumstances but also by relatively stable value systems regarding the normatively prescribed relations between the individual, the state and the market $[9,17,18,48-50]$. Second, the enlightened individual hypothesis assumes that education introduces people to central values of Western civilization-among them equality-which leads to a greater support for government intervention in the labor market [51]. Finally, a feminist view points to gender differences in support for welfare policy, possibly motivated by both a different position vis-à-vis the state and different evaluations of justice [52].

The purpose of this paper is not to evaluate the relative merit of the self-interest hypothesis and the prominent alternative explanations offered above (see Reference [53] for an example of analysis adopting this goal) but rather to expand the understanding of socioeconomic position in regards to redistributive policies. In particular, this paper draws attention to prior conceptualizations of socioeconomic position as additively composed of employment status and occupational status or income, alongside additional aspects of social status, including gender, age and education (e.g., $[9,17,19])$. By contrast, a focus on the working poor draws attention to the intersection of employment and income and allows for differences across social and institutional context in the understanding of these categories and their implication for public policy preferences.

\subsection{Cross-National Differences in the Support for Redistributive Policies}

Cross national research on attitudes towards redistribution has focused on both the overall level of support within each country and on cross-national differences in the association between demographic, social and economic attributes and redistributive policies $[8,9,11,13,19,21-25]$. The backdrop for most research has been Esping-Andersen's [26,27] typology of welfare regimes. Welfare regimes, according to this conceptualization, represent different social justice perceptions and political compromises regarding the relationship between the state, the market and the family, with strikingly different implications for patterns of inequality and the distribution of social risks. Esping-Andersen specifically identified three distinct regimes. In the liberal regime, the market is the primary mechanism for distributing resources, leaving the state to provide only flat-rate benefits in response to proven need. As a result, overall levels of support for redistributive policies are expected to be low, while socioeconomic cleavages are supposed to have a strong impact on such attitudes. The social-democratic regime exhibits a striking contrast to the liberal regime, by providing comprehensive, universal and generous social security benefits that cover most social risks. By ensuring a high degree of decommodification (i.e., the possibility of maintaining a socially accepted standard of living independently of one's status in the market), this regime garners high levels of overall support for redistribution. In addition, socioeconomic differences in this regime are expected to pale in comparison to other social distinctions, notably gender. Finally, the conservative regime is characterized by income-related provisions that maintain status and class distinctions and a strong emphasis on the family as a provider of welfare. This regime is supposed to create strong divisions between insiders holding favorable labor market positions and outsiders occupying weaker labor market positions.

Empirical evidence has generally provided supporting evidence for the arguments about differences in the overall level of support across regimes but not for the arguments about regime-specific 
patterns of socioeconomic cleavages. Overall, support for redistributive policies has been higher in social democratic countries than in the conservative countries, with the liberal countries exhibiting the lowest levels of support [8,11,19,24,25], but see References [21,23]. By contrast, the evidence on cross-national variation in the social basis of support for redistribution has been mixed. Some scholars documented a stronger impact of socioeconomic distinctions in liberal countries, as opposed to conservative and social democratic countries [8]. Others documented a higher impact of socioeconomic distinctions in social democratic countries [19,25], but see References [21,23]. More consistent evidence is reported for gender, marital status and other demographic and social distinctions $[8,11,13,19,23-25]$.

A promising approach addressing these contradictions is presented in studies that directly evaluate the role that specific policies play in shaping attitudes toward welfare policies. As noted by Jæger [13], rather than representing empirical entities, the regimes identified by Esping-Andersen are heuristic ideal types (See also [39]). Because countries rarely fit perfectly into these theoretical ideal types, a more direct assessment of the expectations arising from the welfare regime approach involves examining the association between specific welfare policies and redistributive preferences. Adopting such an approach, Jæger [13] documents a positive (non-linear) association of total public spending with support for redistribution, which stands in line with predictions from the welfare state literature. Contrary to such predictions, the share of benefits in kind as a proportion of total benefits and the net replacement rate were found to be negatively associated with redistributive preferences. A similar approach has been adopted in studies documenting the association between labor market outcomes and welfare policies [33,54].

Building on the approach suggested by Jæger, the current paper aims to extend our understanding of the role that social policy plays in shaping socioeconomic cleavages in attitudes toward redistribution. Motivated by the focus on the working poor, the paper supplements prior research by directing attention to employment protection, which heretofore received little attention in cross-national evaluations of attitudes toward redistribution. The implication of employment protection for redistributive preferences of the working poor, as well of other social policies, will be reviewed in the next section.

\subsection{Labor Market Insiders or Outsiders? Redistributive Preferences by the Working Poor}

An approach focusing on the division between outsiders and insiders in post-industrial labor markets provides a promising template for the analysis of policy preferences by the working poor. The insider-outsider approach has received increasing attention in recent decades from social science scholars [27,35-38]. As formulated by Rueda [37], the approach draws inspiration from the dual labor market approach [55-57], which suggested that the labor market is divided into a primary and secondary markets offering drastically different types and levels of compensation packages and working conditions, and the economic insider-outsider approach [58], which focuses on differences in behavior and preferences between the employed and unemployed.

The argument proposed by Rueda [37] rests on two main pillars. The first claim builds on empirical evidence showing that workers in contemporary labor markets face heterogeneous prospects of employment security, compensation packages and mobility pathways [36,56,59-62]. Two main groups can heuristically be distinguished. Workers with higher levels of either general or firm-specific human capital face favorable compensation prospects and employment security. By contrast, those with lower levels of education and training are confronted with precarious employment prospects, often in part-time or temporary jobs, which offer minimal rights and benefits. A second claim relates these diverging prospects to different policy preferences [37]. Specifically, facing a greater likelihood of experiencing risks such as unemployment, outsiders are expected to favor policies providing monetary assistance and training to persons who are not working or are facing bleak employment prospects. Conversely, insiders are expected to oppose these policies because of their implications for tax policy but are expected to favor employment protection policies, which will potentially shield them from the risks commonly faced by outsiders. Relatively few studies have directly evaluated the 
empirical implications of the insider-outsider policy preferences argument. Rueda [37,38], for example, showed that outsiders report greater support than insiders for governmental provision of training and employment, while insiders report a greater support for employment protection. More recent studies have utilized immigration status and income distinctions as indicators of segmentation between insiders and outsiders $[7,18,42,63]$.

The main argument presented in this paper is that a focus on the policy preferences by the working poor provides a unique opportunity for evaluating the insider-outsider argument. Prior research has documented a greater risk of poverty among working households whose heads lack a college education, are young and are single earners [33]. Considering their overrepresentation among households facing greater needs and possessing more limited resources [35], the self-interest hypothesis would suggest that the working poor will express a stronger degree of support for redistributive policies than non-poor individuals. Hence, in the analysis shown below, we account for several indicators of needs and resources. However, the demographic and human capital characteristics tells us little about the affinity between the dispositions of the working poor and those of non-working poor or of non-poor workers. The insider-outsider argument can be used in extending the scholarship on this topic, and in particular, in formulating two opposing expectations. First, by dint of their employment status, the working poor may feel as part of the insider group and, therefore, will express a degree of support for redistributive policies that are closer to that of non-poor workers than to that of the non-working poor. At the same time, their location at the lower end of the wage ladder, which exposes them to various economic and social risks, might potentially lead them to express a degree of support for redistributive policies that are closer to that expressed by non-working poor individuals than to that expressed by non-poor workers.

These differences among workers can potentially be sensitive to contextual and institutional differences. In particular, settings characterized by broader employment protection will lower the likelihood of experiencing unemployment for the working poor and might, therefore, reduce the gap in redistributive preferences between the working poor and non-poor workers. By contrast, setting typified by provisions of employment training and generous unemployment and income maintenance benefits underscore the common interests that the working poor share with the nonworking poor, and will thus potentially reduce the preference gap between these two groups. It is important to note that these policy dimensions do not exhaust the list of relevant policy domains, excluding, for example, the role of taxation [43]. The domains included in the analysis, however, are the ones that most directly associate with the contemporary understanding of the insider-outsider argument, which focuses mostly on benefits and services provided by the state. The discussion in this section leads to the following research questions:

1. Do the working poor express greater support for redistribution than non-poor workers?

2. Do the working poor express a weaker support for redistribution than non-working poor individuals?

3. Is the gap between the working poor and non-poor workers weaker in countries providing stricter employment protection?

4. Is the gap between the working poor and non-working poor individuals weaker in countries with higher expenditures on employment training and unemployment benefits?

\section{Methodology}

\subsection{Data}

Our study examines the policy preferences of poor workers in hope of providing insights into their perception of their status in the labor market. In particular, we examine whether attitudes by the working poor toward redistribution are closer to the views expressed by poor non-worker individuals or to those of non-poor workers? To examine the respondent-level variables (both dependent and independent), we used two different surveys that provide information on public opinion about social, 
economic and welfare issues. Both surveys had been conducted in various countries and at several time points. We harmonized and combined the surveys, using the relevant variables for our purposes. All the analyses were done on the combined file. We have restricted all analyses to working age individuals (age 25-64). Analyses replicating the analysis while limiting the sample on prime working age individuals (25-54) produced similar results. The final database included 119,740 respondents, from 31 countries in 13 different time points between the years $1985-2010 .{ }^{1}$ It is important to note that not all of the countries were included in all of the years, so for some of them we have more time points than for others. In addition, some of the countries had been divided in some of the time points-and the surveys were conducted separately (e.g., East and West Germany until 1992 and North Ireland in some of the surveys). We have left these surveys divided where it was possible, but in general we preferred to use the same country as a whole.

The two initial datasets were:

(1) The ISSP (international social survey program), which is conducted every year in numerous countries-each year on a different issue. We chose all the modules conducted on the issue of the role of government (years 1985, 1990, 1996 and 2006), and on the issue of social inequality (years 1987, 1992, 1999 and 2009). Especially for the role of government modules, the purpose of these surveys was to examine the respondents' attitudes towards government responsibility and the level of proper intervention in social and economic issues.

(2) The ESS (European social survey), which was conducted in the years 2002, 2004, 2006, 2008 and 2010. Unlike the ISSP, this survey is conducted only in European countries, but it too examines the respondents' attitudes towards various civil, economic and political issues.

\subsection{Variables}

The dependent variable was the attitudes of the respondents toward the government. All the surveys included in the analyses had included a similar question. The ISSP included the following question: "Do you agree or disagree with the statement-it is the responsibility of the government to reduce the differences in income between people with high incomes and those with low incomes"? The ESS included slightly modified version of the question: "Do you agree or disagree with the statement-it is the responsibility of the government to reduce differences in income levels?" In both surveys, respondents were asked to choose an answer from a scale consisting of five categories $(1=$ strongly disagree; $2=$ disagree, $3=$ neither agree nor disagree, 4 = agree, and $5=$ strongly agree). Prior research [42] has indicated that responses to the two formulations of these questions do not significantly differ.

Individual level independent variables: The main independent variable was whether the respondent was indeed a poor worker. We have built this variable by combining two variables available in all the surveys: household income and number of people living in the household. We have divided the first variable by the square root of the second to get a household's equivalized income. Then, we calculated the median household's equivalized income for every country, and built a poverty line variable which was 50 percent of the median income. Our poverty variable, therefore, is a dummy variable determining whether a family's equivalized income is equal to or less than the poverty line. In order to validate those calculations, we also compared the respondent's poverty level based on family income to a low wage variable identifying the lowest $10 \%, 20 \%$ and $25 \%$ of the respondents' household incomes in each country. All those calculations led to similar differences in poverty rates across countries. The final poverty variable includes $16.7 \%$ poor respondents, and $83.3 \%$ who are not poor. Then we combined the poverty variable with a variable documenting labor status-whether the

1 The countries included in the surveys were: Australia, Austria, Belgium, Canada, Chile, Czech Republic, Denmark, Estonia, Finland, France, Germany, Great Britain, Greece, Hungary, Iceland, Ireland, Israel, Italy, Japan, Luxembourg, Netherlands, New Zealand, Norway, Poland, Portugal, Slovak Republic, Slovenia, South Korea, Spain, Sweden, Switzerland, Turkey, and the United States. 
respondent is working or not-to create four dummy variables. The first one indicates that a person belongs to the working poor group, while the remaining three refer to non-poor workers, non-working poor and non-poor non-working individuals. As documented in Table 1 below, we have found that 6.24 percent of the respondents reported belonging to the working poor group in our sample, which roughly corresponds to reports on the poverty rate among workers in OECD countries (cf. [28]).

Table 1. Descriptive Statistics for the macro and micro indicators.

\begin{tabular}{|c|c|c|c|c|c|}
\hline & Total & $\begin{array}{l}\text { Non-Poor } \\
\text { Workers }\end{array}$ & Working Poor & $\begin{array}{c}\text { Poor } \\
\text { Non-Workers }\end{array}$ & $\begin{array}{c}\text { Non-Poor } \\
\text { Non-Workers }\end{array}$ \\
\hline & Mean/Proportion & Mean/Proportion & Mean/Proportion & Mean/Proportion & Mean/Proportion \\
\hline \multicolumn{6}{|l|}{ Level $1^{a}$} \\
\hline Share of total population & 100 & 0.72 & 0.06 & 0.04 & 0.18 \\
\hline \multicolumn{6}{|l|}{$\begin{array}{c}\text { Government should reduce income } \\
\text { differences }\end{array}$} \\
\hline Strongly disagree & 0.05 & 0.05 & 0.03 & 0.02 & 0.03 \\
\hline Disagree & 0.14 & 0.16 & 0.1 & 0.07 & 0.11 \\
\hline Neither agree or disagree & 0.15 & 0.15 & 0.13 & 0.1 & 0.12 \\
\hline Agree & 0.39 & 0.39 & 0.42 & 0.42 & 0.42 \\
\hline Strongly Agree & 0.26 & 0.23 & 0.3 & 0.38 & 0.32 \\
\hline Male & 0.5 & 0.54 & 0.52 & 0.4 & 0.35 \\
\hline \multirow[t]{2}{*}{ Age } & 44.36 & 43.08 & 42.46 & 46.85 & 49.79 \\
\hline & $(10.75)$ & $(10.00)$ & $(9.76)$ & $(11.81)$ & (11.95) \\
\hline \multicolumn{6}{|l|}{ Marital status } \\
\hline $\begin{array}{l}\text { Was married (divorced, separated or } \\
\text { widowed) }\end{array}$ & 0.13 & 0.13 & 0.11 & 0.17 & 0.15 \\
\hline Never married & 0.08 & 0.08 & 0.09 & 0.17 & 0.05 \\
\hline Academic degree & 0.24 & 0.28 & 0.16 & 0.08 & 0.16 \\
\hline Religious & 0.15 & 0.13 & 0.21 & 0.22 & 0.19 \\
\hline Self-employed in current or prior job & 0.13 & 0.15 & 0.19 & 0.08 & 0.08 \\
\hline $\begin{array}{l}\text { Respondent supervises others in current or } \\
\text { prior job }\end{array}$ & 0.33 & 0.37 & 0.25 & 0.17 & 0.25 \\
\hline \multicolumn{6}{|l|}{ Level 2} \\
\hline \multirow[t]{2}{*}{ Employment protection $^{\mathbf{b}}$} & 1.89 & & & & \\
\hline & $(0.85)$ & & & & \\
\hline \multirow[t]{2}{*}{ Unemployment insurance (share of GDP) $^{c}$} & 1.12 & & & & \\
\hline & $(0.79)$ & & & & \\
\hline \multirow[t]{2}{*}{ Active labor market policies (share of GDP) } & 0.61 & & & & \\
\hline & $(0.42)$ & & & & \\
\hline \multirow[t]{2}{*}{ Other transfer payments (share of GDP) $^{c}$} & 0.46 & & & & \\
\hline & $(0.42)$ & & & & \\
\hline $\mathbf{N}$ & 119,740 & & & & \\
\hline $\mathrm{Nj}$ & 179 & & & & \\
\hline Nk & 31 & & & & \\
\hline
\end{tabular}

In addition, we have also included several control variables on the individual level: gender (male $=1)$, age, education (in years), degree (BA and higher degree $=1$, no degree $=0)$, marital status (married $=1$ ), religiosity (whether the responded attends a religious institution at least once a week $=1$ ), and also some control dummy variables regarding to respondent's labor market status: self-employment (yes $=1$ ) and supervision of other workers (yes $=1$ ).

Country/year level independent variables: Besides the micro-level variables, derived from the surveys, we also used macro-level independent variables derived from external data, regarding the 
welfare policy in each country. ${ }^{2}$ In order to examine the county's welfare policy, we used two OECD databases. Tapping the OECD Social Expenditure database, we used three variables which indicate the state's social insurance and assistance policy: (1) Unemployment insurance expenditures as a share of GDP, (b) active labor market policy expenditures as share of GDP and (c) income maintenance social assistance benefits expenditures as a share of GDP. Preliminary analysis revealed that the former two variables were strongly correlated $(\mathrm{r}=0.62)$. Hence, a single score representing both active and passive labor market policy was constructed using factor analysis. The new variable was modestly correlated with income maintenance social assistance benefits variable $(r=0.21)$. We have examined those rates in all the countries included in our database, and in the following time points: 1985, 1990, 1995, 2000, 2005, 2009 and 2010. The second database was the OECD indicators of Employment Protection, which examines the employment protection policies for each country in all the years between 1985 and 2008. ${ }^{3}$ The macro-level variables helped in examining whether the subjective feeling of being an insider or outsider by the working poor is related to the state's welfare policy and the extant of help the country provides to the poor.

\subsection{Analytic Strategy}

The theoretical framework described above was evaluated using a three-level mixed effect ordered logit mode. Each individual in the model is nested within a country/year, which are, in turn, nested within countries. The model includes both country and year fixed effects, allowing a focus on changes within countries rather than differences across countries, which might obscure differences in unobservable stable characteristics of each institutional context. It is important to note that while the model includes time varying covariates at both the individual and macro-level, it assumes that the impact of the covariates remains constant over time.

The model is expressed as follows:

$$
\begin{gathered}
\operatorname{Ln}\left\lfloor\frac{P(Y<l \mid i j k)}{P(Y>=l \mid i j k)}\right\rfloor=\pi 0 j k+\pi j k X 1 i j k \\
\pi 0 j k=\beta 00 k+\beta 01 k Z j k+r 0 j k \\
\beta 00 k=\gamma 000+\gamma 001 W k+u 00 k
\end{gathered}
$$

where $Y$ denotes the degree of agreement with the statement that the government should reduce income differences, 1 refers to the specific level of agreement of individual $i$ nested in a country/year $j$, which, in turn, is nested within a country $k . \pi_{0 j k}$ represents level- 1 intercepts, and $x_{1 j k}$ and $\pi_{1 j k}$ are individual level variables and the coefficients associated with them. At level-2, $\beta_{00 k}$ represents country/year (i.e., level-2) intercepts, $Z_{1 j k}$ and $\beta_{01 k}$ are country/year variables and the regression coefficients associated with them, and $r_{0 \mathrm{jk}}$ a country/year random effect. Finally, at level-3, $\gamma_{000}$ represents country level (i.e., level-3) intercepts (fixed effects) and $u_{00 k}$ a country level random effect.

\section{Results}

Before turning to the multivariate analysis, this section will start with the descriptive statistics, which are presented in Table 1. The table distinguishes among four different groups: non-poor workers, working poor, nonworking poor, and nonworking non-poor individuals. The table provides

\footnotetext{
Missing information for specific years was linearly interpolated.

Alternatives to the OECD Indicators of Employment Protection have recently been developed. A notable example is the Cambridge Center for Business Research Labour Regulation Index (CBR-LRI), which focuses on the degree of protection instead of cost and comprises of 36 indicators providing yearly information and covering broad areas such as forms of employment, regulation of working time, regulation of dismissal, employee representation and industrial action [64]. Perhaps the greatest advantage of the CBR-LRI is the potential of disentangling the various dimensions of employment protection. However, this issue falls beyond the scope of the current paper.
} 
initial insights relating to the first and second research questions. Specifically, about 80 percent of the nonworking poor report agreement or strong agreement with the statement that the government should reduce income differences, compared with 72 percent of the working poor and 62 percent of those who are working but are not poor. The table documents several notable demographic and labor market differences between the groups. Nonworking poor individuals are generally older, and are less likely to be married and to hold an academic degree than non-poor workers and the working poor. The working poor are less likely to hold an academic degree and are more likely to be religious than non-poor workers. Expected differences are also noted for labor market characteristics, with a greater share of non-poor individuals reporting supervisory status in their current job than the working poor, while a greater share of the latter reporting being self-employed. The table also includes the mean scores for the macro-level indicators.

Direct evaluation of the research questions is presented in Table 2. The table features results from three mixed effects ordered logit models: A model containing only the three dummy variables for the distinctions among non-poor workers, working poor, nonworking poor, and nonworking non-poor individuals; a model adding all level-1 control variables; and a model estimating cross-level interactions between the country scores on employment protection, unemployment benefits/active labor market policy and other benefits with the three group dummy variables. While all three models allow addressing the first and second research questions, model 3 addresses the third and fourth questions using an intercept and slope as outcome models [65].

With respect to the first two research questions, the coefficient for non-poor workers is negative and significant in all three models, while the coefficient for poor non-workers is positive and significant. In the third model, for example, non-poor workers are 40 percent $(\exp (-0.51)=0.60)$ less likely than the working-poor to express a greater degree of support for redistribution. By contrast, poor non-working individuals are 24 percent $(\exp (0.36)=1.24)$ more likely than the working-poor to express a greater degree of support for redistribution. These findings are in line with prior research on the self-interest hypothesis, which documented a higher likelihood of supporting welfare policies among low income individuals, persons holding disadvantaged class positions and the unemployed $[9,11,12,15,19]$. These findings are illustrated in Figure 1, which presents the predicted probabilities of reporting agreement or strong agreement with the statement that the government should reduce income differences. In line with the results presented in Table 1, non-working poor individuals report greater agreement with the statement, followed by the working poor, with non-workers showing the lowest (but still non-trivial) degree of support. The degree of support among the working poor (at 76 percent) is notably closer to average degree reported by non-working poor individuals (with 81 percent) than the mean level reported by non-poor workers (at 65 percent). Non-working non-poor individuals express a degree of support that is similar to that of the working poor (with significant differences between this group and both poor non-workers and non-poor workers being revealed), suggesting the existence of two main bifurcations: a gap between poor non-workers and the rest of the population and a gap between non-poor workers and other groups. 
Table 2. Estimates from ordinal mixed effects models predicting support for redistribution of income by the government.

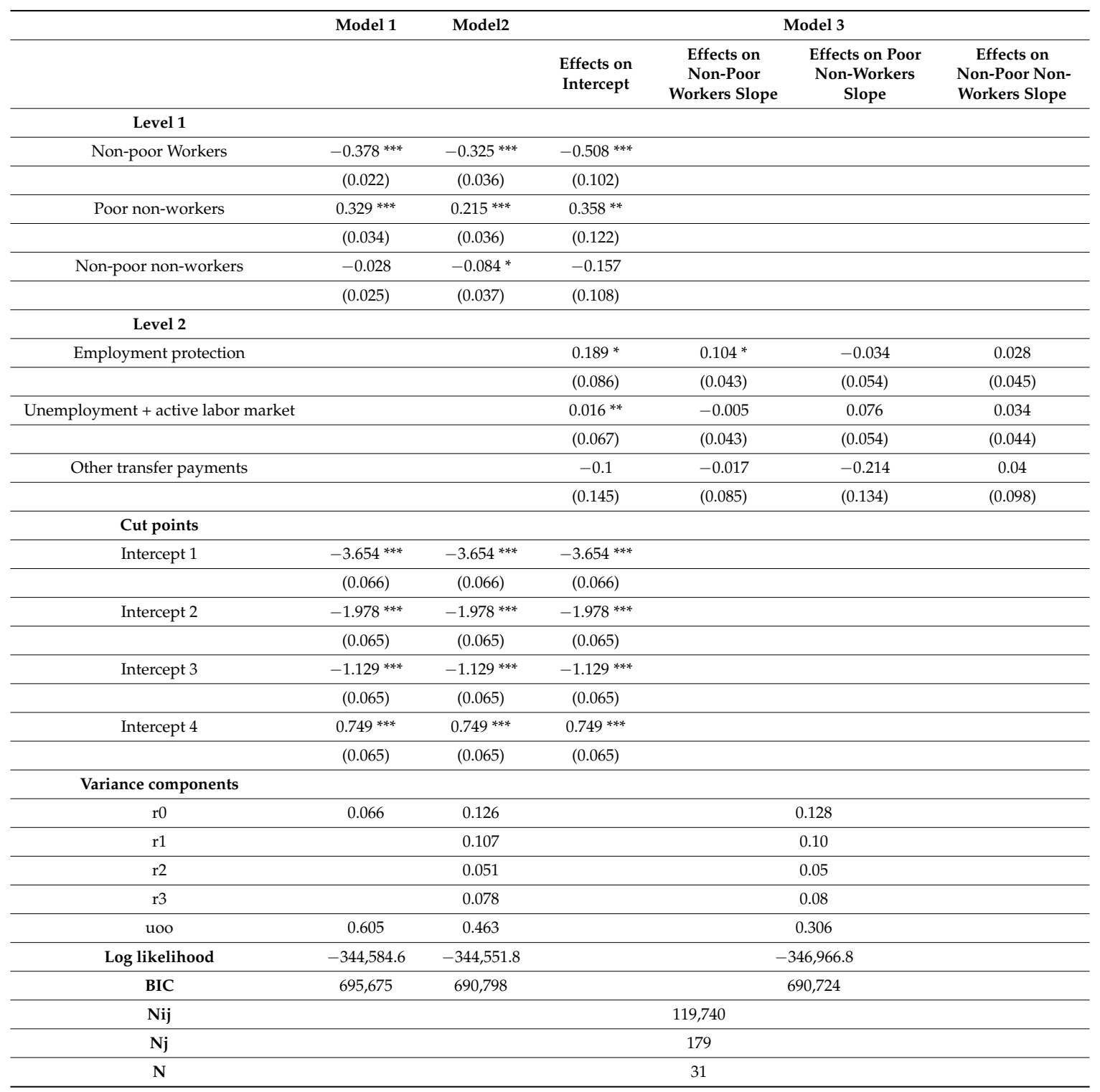

Sources; ISSP 1985, 1987, 1990, 1992, 1996, 1999, 2006, 2009; ESS 2002, 2004, 2006, 2008, 2010; OECD Employment Database; OECD Social Expenditure Database. Note: ${ }^{*} p<0.05$; ${ }^{* *} p<0.01$; ${ }^{* * *} p<0.001$ (two-tailed test; standard errors in parentheses). On the individual level, all models control for gender, age, marital status, post-secondary education, religiosity, self-employment in current or prior job, and supervisory status in current or prior job.

Turning to the last two research questions, the results presented in Table 2 provide evidence only for the impact of employment protection legislation on the non-poor workers slope. This suggests that the policy preference gap between working non-poor individuals and the working poor is smaller in countries providing greater employment protection. It is important to note, however, that a statistically significant preference gap between the working poor and non-poor workers was found at all values of employment protection. By contrast, the impact of unemployment benefits and other benefits on all group distinctions is not significant. The table additionally reports a positive impact of employment protection and a combined measure for unemployment benefits and active labor market policies with the intercept, which means that these policies are associated with a greater degree of support for redistribution. The findings are illustrated in Figure 2, which compares the expected probability of reporting agreement or strong agreement with the statement that the government should reduce income differences between the working poor and non-poor workers in countries with a high and 
low level of employment protection (defined as countries above the 75 percentile and below the 25 percentile on this measure). The figure documents higher support for redistribution in countries with a high level of employment protection, as opposed to countries with a lower level of employment protection. Furthermore, the redistribution preference gap is much smaller in the latter group of countries. Similar results to those reported in Table 2 and Figures 1 and 2 were obtained in analyses utilizing mixed-effects linear models instead of mixed-effects ordinal models, as well as mixed effects logistic models (results not shown).

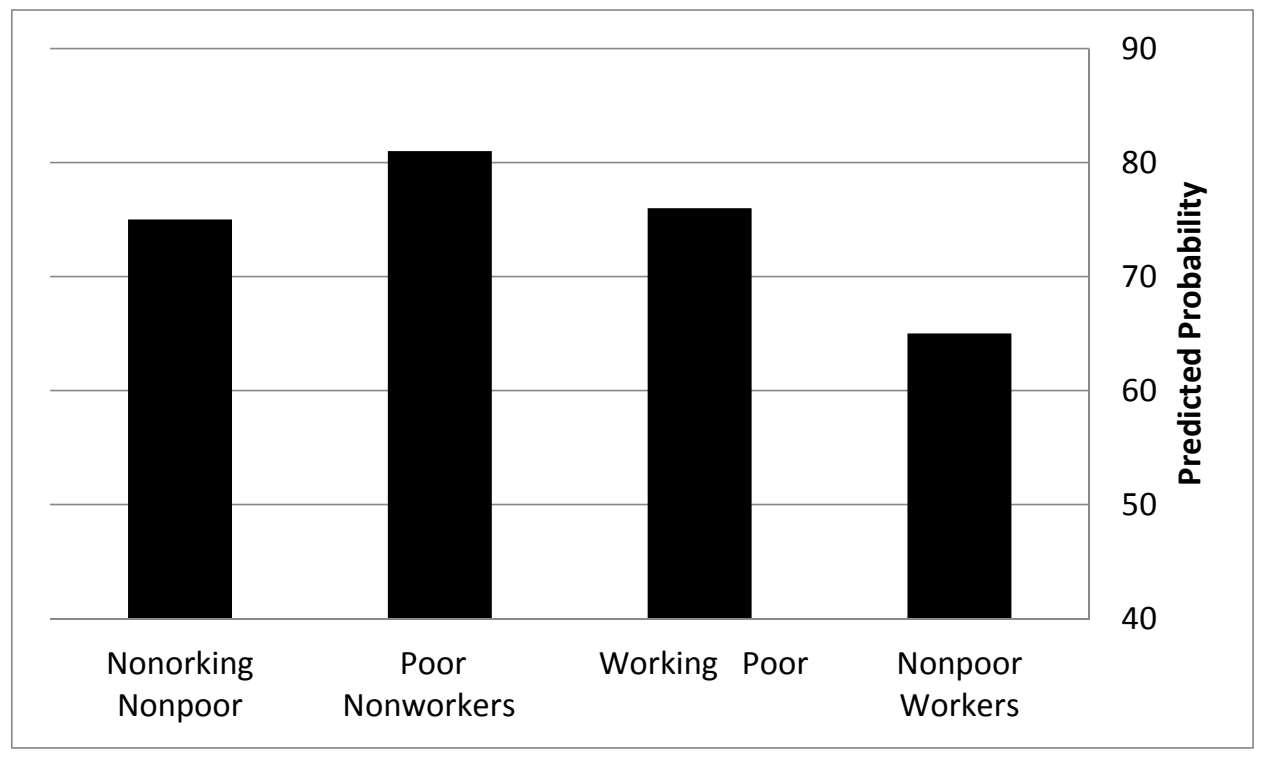

Figure 1. Predicted probability of agreeing or strongly agreeing with the statement that the government should reduce income differences, by employment and poverty status. Sources; ISSP 1985, 1987, 1990, 1992, 1996, 1999, 2006, 2009; ESS 2002, 2004, 2006, 2008, 2010.

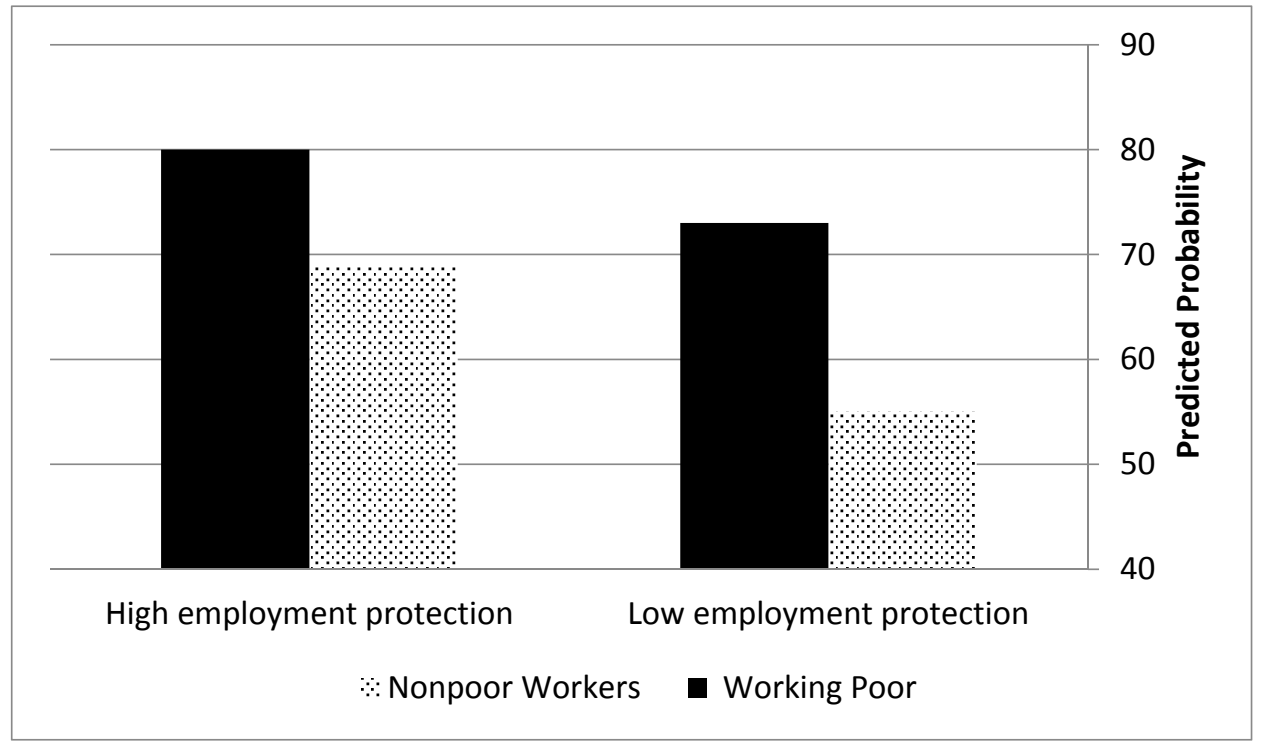

Figure 2. Predicted probability of agreeing or strongly agreeing with the statement that the government should reduce income differences, by employment status, poverty status and country level of employment protection. Sources; ISSP 1985, 1987, 1990, 1992, 1996, 1999, 2006, 2009; ESS 2002, 2004, 2006, 2008, 2010; OECD Employment Database. 


\section{Discussion}

Building on the distinction between labor market insiders and outsiders [27,35-38], this paper examined whether preferences by the working poor more closely resemble those of non-poor workers or those of non-working poor individuals. In addition, aiming to provide a direct assessment of the expectations arising from the welfare regimes approach [13], the paper examined whether institutional differences across countries are associated with shifts in the perceptions of the working poor, thereby increasing their similarity in preferences with either non-poor workers or non-working poor individuals.

Results from this study show that non-working poor individuals report greater agreement with redistribution, followed by the working poor, with non-workers showing the lowest (but still non-trivial) degree of support. The degree of support among the working poor was notably closer to average degree reported by non-working poor individuals than the mean level reported by non-poor workers. This suggests that income is more important in shaping policy preferences than employment status. Moreover, the paper documents a much smaller preference gap between non-poor workers and the working poor and a higher overall level of support for redistribution in countries providing a greater degree of employment protection, as opposed to countries with a lower level of employment protection. By contrast, active and passive labor market policy did not influence the preference gap between the working poor and other groups. These results point to the importance of employment security as a major policy instrument shaping perceptions of policy and employment prospects. In particular, the findings suggest that, in countries providing minimal employment protection, the contrast between the working poor and non-poor workers in policy preferences is much starker than in countries providing a greater degree of employment protection. Hence, employment protection potentially provides a greater sense of common interest between non-poor workers and the working poor, and, consequently, a greater sense of belonging to the insider groups among the latter.

Before we conclude the paper, it is important to highlight two notable weaknesses in the current analysis. The most troubling issue is the reliance of this paper on a single question representing redistributive preferences. The rationale for doing so was the availability of this single question in surveys spanning an extended time period and a broad coverage of countries used in this study. But, the argument presented in this paper has direct implications for preferences relating directly to employment protection, as well as to active labor market policy and unemployment benefits. Another notable omission relates to prominent policy dimensions addressed by the welfare state literature but are not included in the current analysis. Family policy stands as the most obvious candidate for inclusion (e.g., Reference [13]). The main reason for excluding this policy dimension was again the lack of data for the extended time period and the broad coverage of countries included in this study. Finally, the analysis included a limited set of individual-level covariates, which are mostly crudely represented as binary indicators. Both the choice of indicators and the decision to aggregate the responses to those questions were necessitated by the task of harmonizing the information from 31 different countries across 13 different surveys. Considering the abovementioned deficiencies, the results presented in this paper should be viewed as providing only a rudimentary examination of the implications of the insider-outsider argument for redistributive preferences.

We conclude the paper by suggesting two potential avenues for future research that emerge from the current paper. First, an important extension of the current analysis will look at the impact of changes in status over time at the individual level on preferences for redistribution (cf. References $[17,44])$. Such an analysis will require using panel data, as opposed to the cross-sectional data used in the current analysis. Panel data allows adding individual level fixed effects, which will allow accounting for stable differences between individuals. This will provide an important improvement over the current analysis, which only accounts for country-level fixed effects. Second, a promising approach will explore the subjective experiences of the working poor. This approach can most fruitfully be carried out using analysis from in-depth interviews conducted with the working poor. The approach will potentially allow examining whether the working poor perceive their situation as a transient status leading 
to secure employment and favorable compensation prospects or as a relatively stable characteristic reflecting continually precarious employment prospects and minimal rewards and rights. Both suggestions share a focus on the temporality of labor force status and preferences for redistribution.

Funding: This research received no external funding.

Conflicts of Interest: The authors declare no conflicts of interest.

\section{References}

1. Breen, R. Risk, Recommodification and Stratification. Sociology 1997, 31, 473-489. [CrossRef]

2. Hout, M.; Brooks, C.; Manza, J. The democratic class struggle in the United States, 1948-1992. Am. Sociol. Rev. 1995, 60, 805-828. [CrossRef]

3. Lipset, S.M. Political Man; Johns Hopkins University Press: Baltimore, MD, USA, 1981.

4. Marx, K. A Contribution to the Critique of Political Economy; International Library Publishing Company: New York, NY, USA, 1904.

5. McCall, L.; Manza, J. Class differences in social and political attitudes in the United States. In The Oxford Handbook of American Public Opinion and the Media; Shapiro, R.Y., Jacobs, L.R., Eds.; Oxford University Press: Oxford, UK, 2012; pp. 552-570.

6. Offe, C. Democracy against the Welfare State? Structural Foundations of Neoconservative Political Opportunities. Political Theory 1987, 15, 501-537. [CrossRef]

7. Alt, J.; Iversen, T. Inequality, labor market segmentation, and preferences for redistribution. Am. J. Political Sci. 2017, 61, 21-36. [CrossRef]

8. Andreß, H.J.; Heien, T. Four worlds of welfare state attitudes? A comparison of Germany, Norway, and the United States. Eur. Sociol. Rev. 2001, 17, 337-356.

9. Blekesaune, M. Economic conditions and public attitudes to welfare policies. Eur. Sociol. Rev. 2007, 23, 393-403. [CrossRef]

10. D'Anjou, L.; Steijn, A.; Van Aarsen, D. Social position, ideology, and distributive justice. Soc. Justice Res. 1995, 8, 351-384. [CrossRef]

11. Edlund, J. Trust in government and welfare regimes: Attitudes to redistribution and financial cheating in the USA and Norway. Eur. J. Political Res. 1999, 35, 341-370. [CrossRef]

12. Hasenfeld Edlund, Y.; Rafferty, J.A. The determinants of public attitudes toward the welfare state. Soc. Forces 1989, 67, 1027-1048. [CrossRef]

13. Jæger, M.M. Welfare regimes and attitudes towards redistribution: The regime hypothesis revisited. Eur. Sociol. Rev. 2006, 22, 157-170. [CrossRef]

14. Kluegal, J.R.; Smith, E.R. Beliefs about Inequality; Transaction Publishers: Piscataway, NJ, USA, 1986.

15. Lewin-Epstein, N.; Kaplan, A.; Levanon, A. Distributive justice and attitudes toward the welfare state. Soc. Justice Res. 2003, 16, 1-27. [CrossRef]

16. Mosimann, N.; Pontusson, J. Solidaristic unionism and support for redistribution in contemporary Europe. World Politics 2017, 69, 448-492. [CrossRef]

17. Owens, L.A.; Pedulla, D.S. Material Welfare and Changing Political Preferences: The Case of Support for Redistributive Social Policies. Soc. Forces 2014, 92, 1087-1113. [CrossRef]

18. Rueda, D. Food Comes First, Then Morals: Redistribution Preferences, Parochial Altruism, and Immigration in Western Europe. J. Politics 2018, 80, 225-239. [CrossRef]

19. Svallfors, S. Worlds of welfare and attitudes to redistribution: A comparison of eight western nations. Eur. Sociol. Rev. 1997, 13, 283-304. [CrossRef]

20. Wang, A.H.E. Patience moderates the class cleavage in demand for redistribution. Soc. Sci. Res. 2017, 70, 18-27. [CrossRef] [PubMed]

21. Bean, C.; Papadakis, E. A comparison of mass attitudes towards the welfare state in different institutional regimes, 1985-1990. Int. J. Public Opin. Res. 1998, 10, 211-236. [CrossRef]

22. Blekesaune, M.M.; Quadagno, J. Public attitudes toward welfare state policies a comparative analysis of 24 nations. Eur. Sociol. Rev. 2003, 19, 415-427. [CrossRef]

23. Gelissen, J. Popular support for institutionalised solidarity: A comparison between European welfare states. Int. J. Soc. Welf. 2000, 9, 285-300. [CrossRef] 
24. Linos, K.; West, M. Self-interest, Social Beliefs, and Attitudes to Redistribution. Re-addressing the Issue of Cross-national Variation. Eur. Sociol. Rev. 2003, 19, 393-409. [CrossRef]

25. Svallfors, S. Class, attitudes and the welfare state: Sweden in comparative perspective. Soc. Policy Adm. 2004, 38, 119-138. [CrossRef]

26. Esping-Andersen, G. The Three Worlds of Welfare Capitalism; Polity Press: Cambridge, UK, 1990.

27. Esping-Andersen, G. Social Foundations of Postindustrial Economics; University Press: Oxford, UK, 1999.

28. OECD (Organisation for Economic Co-operation and Development). Is Work the Best Antidote to Poverty? In OECD Employment Outlook: Tackling the Jobs Crisis; OECD Publishing: Paris, France, 2009; pp. 165-210.

29. Shipler, D.K. The Working Poor: Invisible in America; Knopf: New York, NY, USA, 2004.

30. Stier, H.; Lewin, A. Does women's employment reduce poverty? Evidence from Israel. Work. Empl. Soc. 2002, 16, 211-230. [CrossRef]

31. Wilson, W.J. When Work Disappears: The World of the New Urban Poor; Vintage Books: New York, NY, USA, 1996.

32. Zuberi, D. Differences that Matter: Social Policy and the Working Poor in the United States and Canada; Cornell University Press: New York, NY, USA, 2006.

33. Brady, D.; Fullerton, A.S.; Moren Cross, J. More than just nickels and dimes: A cross-national analysis of working poverty in affluent democracies. Soc. Probl. 2010, 57, 559-585. [CrossRef] [PubMed]

34. Stier, H. Working and Poor. In The State of the Nation: Society, Economy and Policy; Ben-David, D., Ed.; Taub Center for Social Policy Studies in Israel: Jerusalem, Israel, 2011; pp. 135-180.

35. Andre $\beta$, H.J.; Lohmann, H. The Working Poor in Europe: Employment, Poverty and Globalization; Edward Elgar Publishing: Northampton, MA, USA, 2008.

36. Esping-Andersen, G. A welfare state for the 21st century. In The Welfare State Reader; Pierson, C., Castles, F.G., Eds.; Polity Press: Cambridge UK, 2006; pp. 434-454.

37. Rueda, D. Insider-outsider politics in industrialized democracies: The challenge to social democratic parties. Am. Political Sci. Rev. 2005, 99, 61-74. [CrossRef]

38. Rueda, D. Social democracy and active labour-market policies: Insiders, outsiders and the politics of employment promotion. Br. J. Political Sci. 2006, 36, 385-406. [CrossRef]

39. Brady, D.; Bostic, A. Paradoxes of social policy: Welfare transfers, relative poverty, and redistribution preferences. Am. Sociol. Rev. 2015, 80, 268-298. [CrossRef]

40. Lupu, N.; Pontusson, J. The structure of inequality and the politics of redistribution. Am. Political Sci. Rev. 2011, 105, 316-336. [CrossRef]

41. VanHeuvelen, T. Unequal views of inequality: Cross-national support for redistribution, $1985-2011$. Soc. Sci. Res. 2017, 64, 43-66. [CrossRef] [PubMed]

42. Breznau, N.; Eger, M.A. Immigrant presence, group boundaries, and support for the welfare state in Western European societies. Acta Sociol. 2016, 59, 195-214. [CrossRef]

43. Berens, S.; Gelepithis, M. Welfare State Structures, Inequality, and Public Attitudes Toward Progressive Taxation. Socio-Econ. Rev. 2018. [CrossRef]

44. Margalit, Y. Explaining social policy preferences: Evidence from the Great Recession. Am. Political Sci. Rev. 2013, 107, 80-103. [CrossRef]

45. Chong, D.; Citrin, J.; Conley, P. When Self-Interest Matters. Political Psychol. 2001, 22, 541-570. [CrossRef]

46. Lynch, J.; Myrskylä, M. Always the third rail? Pension income and policy preferences in European democracies. Comp. Political Stud. 2009, 42, 1068-1097. [CrossRef]

47. Mughan, A. Economic insecurity and welfare preferences: A micro-level analysis. Comp. Politics 2007, 39, 293-310.

48. Schlozman, K.L.; Verba, S. Insult to Injury: Unemployment, Class, and Political Response; Harvard University Press: Cambridge, UK, 1979.

49. Alesina, A.F.; Giuliano, P. Preferences for Redistribution. In National Bureau of Economic Research; Working Paper No. 14825; NBER: Cambridge, MA, USA, 2009.

50. Feldman, S.; Zaller, J. The political culture of ambivalence: Ideological responses to the welfare state. Am. J. Political Sci. 1992, 36, 268-307. [CrossRef]

51. Robinson, R.V.; Bell, W. Equality, success, and social justice in England and the United States. Am. Sociol. Rev. 1987, 43, 125-143. [CrossRef]

52. Arts, W.; Gelissen, J. Welfare states, solidarity and justice principles: Does the type really matter? Acta Sociol. 2001, 44, 283-299. [CrossRef] 
53. Guillaud, E. Preferences for redistribution: An empirical analysis over 33 countries. J. Econ. Inequal. 2013, 11, 57-78. [CrossRef]

54. Lohmann, H. Welfare states, labour market institutions and the working poor: A comparative analysis of 20 European countries. Eur. Sociol. Rev. 2008, 25, 489-504. [CrossRef]

55. Doeringer, P.B.; Piore, M. Internal Labor Markets and Manpower Analysis; D.C. Heath and Company: Lexington, MA, USA, 1971.

56. Kalleberg, A.L.; Wallace, M.; Althauser, R.P. Economic segmentation, worker power, and income inequality. Am. J. Sociol. 1981, 87, 651-683. [CrossRef]

57. Kaufman, R.L.; Hodson, R.; Fligstein, N.D. Defrocking dualism: A new approach to defining industrial sectors. Soc. Sci. Res. 1981, 10,1-31. [CrossRef]

58. Lindbeck, A.; Snower, D.J. Wage Setting, Unemployment, and Insider-Outsider Relations. Am. Econ. Rev. 1986, 76, 235-239.

59. Harrison, B. Lean and Mean: Why Large Corporations Will Continue to Dominate the Global Economy; The Guilford Press: New York, NY, USA, 1997.

60. Kalleberg Arne, L.; Reskin, B.F.; Hudson, K. Bad jobs in America: Standard and nonstandard employment relations and job quality in the United States. Am. Sociol. Rev. 2000, 65, 256-278. [CrossRef]

61. DiPrete, T.A.; Goux DMaurin, E.; Quesnel-Vallee, A. Work and pay in flexible and regulated labor markets: A generalized perspective on institutional evolution and inequality trends in Europe and the US. Res. Soc. Strat. Mobil. 2006, 24, 311-332. [CrossRef]

62. Tilly, C. Labor market inequality, past and future: A perspective from the United States. In Gender Segregation: Division of Work in Post-Industrial Welfare States; Gonas, L., Karlsson, J.C., Eds.; Ashgate Publishing, Ltd.: Farnham, UK, 2006; pp. 13-28.

63. Steele, L.G. Ethnic diversity and support for redistributive social policies. Soc. Forces 2016, 94, $1439-1481$. [CrossRef]

64. Deaking, S.; Malmberg, J.; Sarkar, P. How do labour laws affect unemployment and the labor share of national income? The experience of six OECD countries, 1970-2010. Int. Labour Rev. 2014, 153, 1-27. [CrossRef]

65. Raudenbush, S.W.; Bryk, A.S. Hierarchical Linear Models: Applications and Data Analysis Methods; Volume 1, Sage: Newcastle upon Tyne, UK, 2002.

(C) 2018 by the author. Licensee MDPI, Basel, Switzerland. This article is an open access article distributed under the terms and conditions of the Creative Commons Attribution (CC BY) license (http:/ / creativecommons.org/licenses/by/4.0/). 